\title{
Streptococcus didelphis sp. nov., a streptococcus with marked catalase activity isolated from opossums (Didelphis virginiana) with suppurative dermatitis and liver fibrosis
}

\author{
Fred R. Rurangirwa, ${ }^{1}$ Charlene A. Teitzel, ${ }^{2}$ Jing Cui, ${ }^{2}$ Dorothy M. French, ${ }^{1}$ \\ Patrick L. McDonough ${ }^{3}$ and Thomas Besser ${ }^{1}$
}

Author for correspondence: Fred R. Rurangirwa. Tel: +1 509335 6023. Fax: + 15093358529. e-mail: ruvuna@vetmed.wsu.edu

\footnotetext{
1 Department of Veterinary Microbiology and Pathology, Washington State University, Pullman, WA 99164-7040, USA

2 Washington Animal Diseases Diagnostic Laboratory, Washington State University, Pullman, WA 99164-2037, USA

3 Department of Population Medicine and Diagnostic Science, College of Veterinary Medicine, Cornell University, Ithaca, NY 14853, USA
}

\begin{abstract}
$\beta$-Haemolytic, catalase-positive, Gram-positive cocci that formed chains in broth media but did not react with Lancefield group antisera were isolated from skin lesions, spleen, liver and lungs of nine opossums, including eight from a research colony and one from a wildlife rehabilitation organization. The isolates had vigorous catalase activity that was retained on initial passage on non-blood-containing media, but this activity was lost in subsequent passages. The use of standard phenotypic tests did not lead to satisfactory identification of these organisms beyond the genus level, even if the aberrant catalase reaction was not considered. The 16S rRNA gene sequence of the isolates was most similar (96\%) to Streptococcus dysgalactiae, but distinct from that species as $16 \mathrm{~S}$ rRNA gene similarity of different strains of $S$. dysgalactiae was $>99 \%$. Characterization of biochemical reactions and cell-wall fatty acid profiles also revealed significant differences between the opossum isolates and all other known Streptococcus spp., thus it is proposed as a new species with the name Streptococcus didelphis, sp. nov. The type strain is ATCC 700828'.
\end{abstract}

Keywords: streptococcus, catalase-positive, $\beta$-haemolytic, 16S rDNA sequence

\section{INTRODUCTION}

Streptococci are usually found as parasites of humans and other animals. While some streptococci function as virulent pathogens, other strains live harmoniously with their hosts as avirulent commensals. Streptococci colonize the skin and mucous membranes and can be isolated as part of the normal flora of the alimentary, respiratory and genital tracts (Ruoff, 1995).

Various disease processes result from streptococcal infections, and their development depends on various factors such as portal of entry, animal species and streptococcal species (Carter et al., 1995). Although usually localized, streptococcal infections may become

\footnotetext{
Abbreviations: FAME, fatty acid methyl ester; WADDL, Washington Animal Diseases Diagnostic Laboratory.

The GenBank accession numbers for the 16S rRNA gene sequences of Streptococcus didelphis are AF176100 (isolate W95-4849), AF176101 (W95108899-177), AF176102 (W95-108899-131), AF176103 (W94-11374-1'), AF176104 (W94-12010), AF176105 (W95-111064), AF176106 (W95-2085-1), AF176107 (W95-3349-1), AF176108 (W95-3565-7).
}

septicaemic or bactaeremic, resulting in death or foci of infection in various locations (Burns et al., 1998). Herein we describe the isolation, genetic and biochemical characterization of novel, catalase-positive streptococci from opossums displaying septicaemia and cutaneous necrotic lesions.

\section{METHODS}

Opossums. Between 1994 and 1998, nine dead opossums, including eight from a research colony and one from a wildlife rehabilitation organization, were submitted to the Washington Animal Diseases Diagnostic Laboratory (WADDL) with histories of skin bruising followed by sudden deaths. All the carcasses were evaluated grossly and histologically. Tissues from apparently affected organs were submitted for bacterial culture and isolation.

Bacterial type strains. Bacterial strains analysed for comparison with the streptococci isolated from opossums are listed in Table 1.

Bacterial isolation. Opossum tissues, including skin, lung, liver, spleen and kidney, were routinely plated onto $5 \%$ sheep blood Columbia agar (CBA) and MacConkey agar 
Table 1. Streptococcal strains analysed for comparison with opossum isolates

\begin{tabular}{|c|c|}
\hline Species/strain & Accession no.* \\
\hline S. dysgalactiae ATCC 27957 & AB002484 \\
\hline S. dysgalactiae ATCC 43078 & AB002485 \\
\hline S. dysgalactiae A1 & AB002486 \\
\hline S. dysgalactiae A25 & AB002489 \\
\hline S. dysgalactiae A7 & AB002492 \\
\hline S. dysgalactiae V26 & AB002512 \\
\hline S. porcinus ATCC $43138^{\mathrm{T}}$, NCTC $10999^{\mathrm{T}}$ & AB002523 \\
\hline S. uberis ATCC $27958^{\mathrm{T}}$ & AB002527 \\
\hline S. uberis & U41048 \\
\hline S. agalactiae ATCC $13813^{\mathrm{T}}$, NCTC $8181^{\mathrm{T}}$ & AB002479 \\
\hline S. agalactiae & AF015927 \\
\hline \multicolumn{2}{|l|}{ Opossum isolates } \\
\hline W94-11374-1 ${ }^{\mathrm{T}}\left(\right.$ ATCC $\left.700828^{\mathrm{T}}\right)$ & AF176103 \\
\hline W94-12010 & AF176104 \\
\hline W95-111064 & AF176105 \\
\hline W95-2085-1 & AF176106 \\
\hline W95-3349-1 & AF176107 \\
\hline W95-3565-7 & AF176107 \\
\hline W95-4849 & AF 176100 \\
\hline W95-108899-131 & AF176102 \\
\hline W95-108899-177 & AF176101 \\
\hline
\end{tabular}

* GenBank 16S rRNA gene accession number.

plates, and inoculated into thioglycollate broth enrichment medium. Colonies on the CBA were Gram stained to establish morphology.

Phenotypic studies. Physiological characterization of the isolates was initially studied by plating onto CBA and MacConkey agar incubated at $37^{\circ} \mathrm{C}$. Catalase activity was detected by dispersing colonies in $3 \%$ hydrogen peroxide and checking for macroscopically evident bubble formation. Because the opossum isolates were Gram-positive cocci and formed chains in broth media, yet produced strong bubble formation in $3 \%$ hydrogen peroxide, catalase activity was further demonstrated by a semi-quantitative catalase test (Master, 1994), modified by use of tryptic soy agar deeps and incubation of the inoculated deeps for $2 \mathrm{~d}$ prior to testing. Controls included Staphylococcus aureus ATCC 29213 (positive), and Enterococcus faecalis ATCC 29212 and Streptococcus equi (negative). Further biochemical tests were performed by inoculation of the API 20 STREP system (bioMérieux) according to the manufacturer's instructions, but incubation was done under aerobic conditions at $37^{\circ} \mathrm{C}$ for $24 \mathrm{~h}$.

Fatty acid methyl ester (FAME) analysis. Two different opossum bacterial isolates were grown on trypticase soy agar with $5 \%$ sheep blood in $6 \% \mathrm{CO}_{2}$ at $37^{\circ} \mathrm{C}$, and harvested from the third quadrant at $24 \mathrm{~h}$. Bacterial cells were weighed and bacterial cell lipids were saponified by addition of $1 \mathrm{ml} \mathrm{NaOH} /$ methanol (45 g NaOH, $150 \mathrm{ml}$ methanol, $150 \mathrm{ml}$ distilled water) to each tube, vortexing (15 s) and heating $\left(100^{\circ} \mathrm{C}, 5 \mathrm{~min}\right)$. Tubes were then revortexed $(15 \mathrm{~s})$ and reheated $\left(100{ }^{\circ} \mathrm{C}, 25 \mathrm{~min}\right)$. After cooling the tubes to room temperature, free fatty acids were methylated by adding $2 \mathrm{ml}$ hydrochloric acid/methanol (325 $\mathrm{ml} 6 \mathrm{M} \mathrm{HCl}, 275 \mathrm{ml}$ methanol), vortexing (15 s) and reheating $\left(80^{\circ} \mathrm{C}, 10 \mathrm{~min}\right)$. After rapid cooling to room temperature, FAMEs were extracted from the acidic aqueous phase by hexane/methyl-tert butyl ether solution $(1: 1$, $\mathrm{v} / \mathrm{v} ; 1.25 \mathrm{ml})$ and mixed by rotation $(10 \mathrm{~min})$. The acidic aqueous phase was aspirated and discarded, and the FAME extract layer was washed and neutralized ( $3 \mathrm{ml} 10 \cdot 8 \mathrm{~g} \mathrm{NaOH}$ in $900 \mathrm{ml}$ distilled water), and placed in an auto-sampler vial for chromatography. FAMEs were separated with a Hewlett Packard 5890 gas-liquid chromatograph fitted with a capillary column (Ultra2, cross-linked $5 \%$ phenyl methyl siloxane, $25 \mathrm{~m} \times 0.2 \mathrm{~mm}$ i.d. $\times 0.33 \mathrm{Fm}$ film thickness; Hewlett Packard) coated with phenyl methyl silicone and detected by flame ionization using hydrogen as the carrier gas. FAMEs were identified using the MIDI-Sherlock System (Microbial ID). A calibration mixture containing fatty acid methyl esters (straight-chain saturated nC9:0 to nC20:0, plus 2 and 3 hydroxy acids) in $0.8 \mathrm{ml}$ hexane was used as an identification standard. CLIN version 3.9 and version 4.0 were searched for matches with the unknown bacterial isolates (Microbial ID).

Antibiotic susceptibility tests. These were performed by microbroth dilution (Accumed) after a $24 \mathrm{~h}$ incubation at $37^{\circ} \mathrm{C}$ under aerobic conditions.

Chromosomal DNA extraction and PCR amplification. DNA was extracted from a heavy suspension of the isolate grown on blood agar using Puregene DNA Isolation Kit (Gentra Systems) under the conditions stipulated by the manufacturer. The DNA extract was used as a template in a PCR incorporating the broad-spectrum $16 \mathrm{~S}$ rRNA gene primers (forward 5'-AGA GTT TGA TCC TGG-3' and reverse 5'TAC CTT GTT ACG ACT T-3') selected from the conserved sequences at the beginning and end of the eubacterial kingdom 16S rDNA (Wilson et al., 1990; Woese, 1987). The

Table 2. Primers used for sequencing in this study

\begin{tabular}{|llc|}
\hline Primer & \multicolumn{1}{c|}{ Sequence $\left(5^{\prime} \rightarrow \mathbf{3}^{\prime}\right)$} & Position \\
\hline Forward & & \\
F1-M13 & GTTTTCCCAGTCACGACGTTGTA & \\
F2 & CTATGAAATGGACCTGCGTTG & $220-240$ \\
F3 & CTCTCTGGTCTGTAACTGA & $734-752$ \\
F4 & CTCAGTTCGGATTGTAGG & $1295-1313$ \\
Reverse & & \\
R1-M13 & TTGTGAGCGGATAACAATTTC & \\
R2 & CTAAGGGAATGTCTATCT & $492-475$ \\
R3 & CTACACCATTCTTCTCTAACAACAG & $1070-1046$ \\
\hline
\end{tabular}


primers were purchased from Life Technologies. The PCR was carried out as previously described (Rurangirwa et al., 1999). The success of the amplification was determined by ethidium bromide staining following the resolution of products by $1.5 \%$ agarose gel electrophoresis.

Cloning, sequencing and sequence analysis. The amplified fragment was ligated into the pCR2.1 vector (Invitrogen) and used to transform Escherichia coli as described previously (Rurangirwa et al., 1999). Nucleotide sequencing of the recombinant inserts from selected colonies was performed as described previously (Rurangirwa et al., 1999). Cloning the amplified fragment into pCR2.1 enabled sequencing of the whole amplicons, initially using M13 forward and reverse primers (Invitrogen) approximately 100 bases up- and downstream from the cloning site, and subsequently with commercially synthesized specific primers (Life Technologies) selected as sequence information was obtained. Table 2 shows the primers used to sequence through the entire 16S rRNA gene amplicons of the Streptococcus isolates. Sequence data derived from each primer were compared, aligned and combined into a single, almost complete $16 \mathrm{~S}$ rRNA gene sequence. The sequence was compared with all eubacterial $16 \mathrm{~S}$ rRNA gene sequences available in the GenBank database by using the BLAST and FASTA programs online (Pearson \& Lipman, 1988).

The 16S rRNA gene sequence of the isolates, together with those found to be most similar in the FASTA analysis and sequences of other members of the genus Streptococcus were then aligned by using CLUSTAL W (Higgins \& Sharp, 1989). The resulting alignment was first edited by removal of sequences at the $5^{\prime}$ and $3^{\prime}$ ends of longer sequences so that their lengths matched that of the shortest sequence. Finally, ambiguous base positions were taken out to yield a final alignment suitable for use in phylogenetic reconstructions. The data were analysed by using the distance matrix, parsimony and maximum-likelihood programs (DNADIST/ neighbour joining, DNAPARS and DNAML, respectively) of the PHYLIP (Felsenstein, 1993) package. The stability of reconstructions inferred by each method were assessed by generation of 100 bootstrap samples (SEQBOOT) and construction of strict majority rule consensus trees (CONSENSE).

\section{RESULTS}

\section{Pathological findings}

The opossums ranged in age from approximately 8 to 45 months, six were females and three were males. All opossums had lesions in both liver and skin, and additional findings varied among the animals (Table 3). Grossly, the livers were fibrous, firm, mottled redbrown to yellow with a prominent reticular pattern. Cutaneous lesions varied from small erosions to ruptured subcutaneous abscesses. Affected areas included the thoracic limbs (2/9 animals), lateral pelvic limbs (4/9), tail (1/9), and the head and neck (2/9). Pressure points such as the elbow, point of the hip and foot pads were most commonly affected. In one animal (95-04849), the skin was denuded from the dorsal left pelvis to the tarsus distally and perineum caudally.

Histologically, in seven opossums the predominant lesion was liver fibrosis. The distribution of hepatic fibrosis was centrilobular (4/9 animals), periportal $(1 / 9)$ or both $(2 / 9)$. The other two opossums had multifocal, random areas of hepatic necrosis and suppuration in addition to centrilobular fibrosis. In most instances, mature fibrous connective tissue extended along hepatic sinusoids in the space of Disse and bridged centrilobular areas. Fibrous tissue separated and isolated individual or small groups of hepatocytes in the most severely affected areas. Mild accumulations of lymphocytes, plasma cells and few macrophages were present in portal areas. While various degrees of hepatic fibrosis were seen in all nine opossums reported here, these hepatic lesions have not been a consistent feature of additional wild opossums examined. However, these additional opossums did show skin lesions and septicaemia, and pure cultures of catalase-positive streptococci, identical to those described here, were isolated from their tissues.

Skin from five of the opossums was evaluated histologically. Cutaneous lesions included suppurative, necrotizing dermatitis (3/5 animals) with extensive serocellular crusts $(1 / 5)$ and necrotizing cellulitis $(2 / 5)$ or dermal fibrosis $(1 / 5)$. Opossums with cellulitis also had myositis associated with suppurative inflammation and myonecrosis. Colonies of Gram-positive cocci were admixed with neutrophils and necrotic cellular debris in three of the affected opossums. Samples from skin lesions, livers, spleens, kidneys and lungs from all these cases were submitted for culture for bacteria isolation.

\section{Phenotypic studies}

The isolates under study grew as small, translucent, $\beta$ haemolytic colonies on CBA. On broth culture, the organisms were Gram-positive cocci in chains. Initial subcultures grown on tryptic soy agar or MuellerHinton agar were strongly catalase positive, but with additional passages the positive catalase reaction was rapidly lost. On semi-quantitative catalase testing, the opossum isolates produced $16 \cdot 3 \pm 4 \cdot 0$ (mean \pm SD) $\mathrm{mm}$ on the first passage on tryptic soy agar and $0 \cdot 22 \pm 0.44 \mathrm{~mm}$ on the second passage. For comparison, Staphylococcus aureus ATCC 29213 tested identically produced $>45 \mathrm{~mm}$ on first passage, and Streptococcus equi and Enterococcus faecalis generated $0 \mathrm{~mm}$. The isolates were highly susceptible to most antimicrobial drugs tested (Table 4). The results of biochemical and physiological assessment are presented in Table 5.

FAMEs detected in analysis of the opossum bacterial isolates included 12:0, 14:0, 15:0,16:1 $\omega 9 c, 16: 1 \omega 5 c$, $16: 0, \quad 17: 0$ anteiso, $17: 1 \omega 8 c, 17: 0,18: 1 \omega 9 c$, $18: 1 \omega 7 c, 18: 0,20: 4 \omega 6,9,12,15 c$, summed feature 3 $(16: 1 \omega 7 c / 15$ iso $2-\mathrm{OH}$ and $15: 0$ iso $2-\mathrm{OH} /$ $16: 1 \omega 7 c)$ and summed feature $5(18: 2 \omega 6,9 c / 18: 0$ anteiso and 18:0 anteiso/18:2 $\omega 6,9 c)$, where summed features are groups of FAMEs that cannot be resolved by GC analysis due to peak overlap. The closest matches to the two analysed isolates in the CLIN library, version 3.9, were Streptococcus anginosus (similarity index $0 \cdot 327,0 \cdot 320$ ), Streptococcus equinus 
Table 3. Gross and histopathological lesions from nine opossums culture positive for Streptococcus didelphis

\begin{tabular}{|c|c|c|c|c|}
\hline Case & Gender & Liver & Skin & Other \\
\hline $94-12010$ & $\mathrm{~F}$ & $\begin{array}{l}\text { Random suppurative hepatitis } \\
\text { with coccoid bacteria }\end{array}$ & $\begin{array}{l}\text { Suppurative dermatitis in right } \\
\text { axilla }\end{array}$ & $\begin{array}{l}\text { Meningitis, interstitial } \\
\text { pneumonia }\end{array}$ \\
\hline $94-03565-176$ & M & Centrilobular fibrosis & $\begin{array}{l}\text { Suppurative dermatitis and } \\
\text { cellulitis left axilla, right flank } \\
\text { and scrotum }\end{array}$ & $\begin{array}{l}\text { Splenic extra-medullary } \\
\text { haematopoesis, interstitial } \\
\text { pneumonia }\end{array}$ \\
\hline $94-03565-164$ & $\mathrm{~F}$ & $\begin{array}{l}\text { Random suppurative hepatitis } \\
\text { with centrilobular fibrosis }\end{array}$ & $\begin{array}{l}\text { Ulcers on lateral plantar surface } \\
\text { of hind feet* }\end{array}$ & $\begin{array}{l}\text { Suppurative nephritis, } \\
\text { meningitis, splenic abscess }\end{array}$ \\
\hline $95-02085$ & $\mathrm{~F}$ & $\begin{array}{l}\text { Periportal and centrilobular } \\
\text { fibrosis }\end{array}$ & $\begin{array}{l}\text { Ulcers on medial right elbow } \\
\text { and front digits (also lacking } \\
\text { toenails near affected skin)* }\end{array}$ & $\begin{array}{l}\text { Interstitial pneumonia, } \\
\text { myocardial fibrosis with } \\
\text { suppurative myocarditis, } \\
\text { interstitial nephritis }\end{array}$ \\
\hline $95-03349$ & M & Periportal fibrosis & $\begin{array}{l}\text { Widespread fibrosis and } \\
\text { suppurative dermatitis, } \\
\text { ulcerated tail, cellulitis (right } \\
\text { forelimb) }\end{array}$ & $\begin{array}{l}\text { Interstitial pneumonia, } \\
\text { necrotizing enteritis }\end{array}$ \\
\hline $95-04849$ & M & $\begin{array}{l}\text { Periportal and centrilobular } \\
\text { fibrosis }\end{array}$ & $\begin{array}{l}\text { Left lateral pelvic limb denuded, } \\
\text { suppurative necrotizing } \\
\text { dermatitis with coccoid bacteria } \\
\text { (ear tips) }\end{array}$ & Interstitial pneumonia \\
\hline $95-108899-131$ & $\mathrm{~F}$ & Centrilobular fibrosis & $\begin{array}{l}\text { Serocellular crusts on right } \\
\text { dorsal midline* }\end{array}$ & $\begin{array}{l}\text { Glomerulopathy; hepatic } \\
\text { lipidosis }\end{array}$ \\
\hline $95-108899-177$ & $\mathrm{~F}$ & Centrilobular fibrosis & $\begin{array}{l}\text { Ulcers and cellulitis on the } \\
\text { ventrum of head and neck }\end{array}$ & $\begin{array}{l}\text { Increased myeloid precursors, } \\
\text { spleen myositis, salivary } \\
\text { adenitis }\end{array}$ \\
\hline $95-111064$ & $\mathrm{~F}$ & $\begin{array}{l}\text { Centrilobular fibrosis and } \\
\text { necrosis }\end{array}$ & $\begin{array}{l}\text { Ulcers and necrosis on the left } \\
\text { lateral hind limb* }\end{array}$ & $\begin{array}{l}\text { Interstitial pneumonia, } \\
\text { adrenalitis, tracheitis, splenitis, } \\
\text { myocarditis, gastritis }\end{array}$ \\
\hline
\end{tabular}

* Gross lesions only.

Table 4. MICs of selected antimicrobials for Streptococcus dide/phis isolates as determined by microbroth dilution

\begin{tabular}{|lcc|}
\hline Antimicrobial & $\mathbf{M I C}_{\mathbf{5 0}}\left(\boldsymbol{\mu} \mathbf{g ~ m l}^{-\mathbf{1}}\right)$ & $\mathbf{M I C}$ range \\
\hline Amikacin & 16 & $\leqslant 8-64$ \\
Amoxicillin/clavulanic acid & $\leqslant 4 \cdot 00$ & $\leqslant 4 \cdot 00$ \\
Ampicillin & $\leqslant 0 \cdot 12$ & $\leqslant 0 \cdot 12$ \\
Ceftiofur & $\leqslant 1 \cdot 00$ & $\leqslant 1 \cdot 00$ \\
Cephalothin & $\leqslant 4 \cdot 00$ & $\leqslant 4 \cdot 00$ \\
Chloramphenical & $\leqslant 4 \cdot 00$ & $\leqslant 4 \cdot 00$ \\
Clindamycin & $\leqslant 0 \cdot 50$ & $\leqslant 0 \cdot 50$ \\
Enrofloxacin & $0 \cdot 5$ & $\leqslant 0 \cdot 25-1 \cdot 0$ \\
Erythromycin & $\leqslant 0 \cdot 50$ & $\leqslant 0 \cdot 50-1 \cdot 0$ \\
Gentamicin & $\leqslant 2$ & $\leqslant 2-8 \cdot 0$ \\
Penicillin G & $\leqslant 0 \cdot 12$ & $\leqslant 0 \cdot 12$ \\
Rifampicin & $\leqslant 1 \cdot 0$ & $\leqslant 1 \cdot 0$ \\
Tetracycline & $\leqslant 4 \cdot 0$ & $\leqslant 4 \cdot 0$ \\
Ticarcillin & $\leqslant 16 \cdot 00$ & $\leqslant 16 \cdot 00$ \\
Ticarcillin/clavulanic acid & $\leqslant 16 \cdot 00$ & $\leqslant 16 \cdot 00$ \\
Trimethoprim/sulfadiazine & $\leqslant 0 \cdot 50 / 10$ & $\leqslant 0 \cdot 50 / 9 \cdot 5-$ \\
& & $>2 \cdot 0 / 38$ \\
\hline
\end{tabular}

$(0 \cdot 307,0 \cdot 289)$ and Streptococcus pyogenes $(0 \cdot 297$, $0.363)$, and in version 4.0 were $S$. pyogenes $(0 \cdot 267$, $0.311)$, S. equinus $(0 \cdot 248,0.231)$ and Streptococcus anginosus $(0 \cdot 152)$. Since similarity indices under 0.500 are not considered good matches to a library entry, these results indicate that the opossum isolates were most similar to streptococci, but insufficiently similar to any single Streptococcus species to produce an acceptable identification.

\section{PCR amplification and sequence analysis of 16S rRNA genes of the Streptococcus isolates}

Conserved eubacterial 16S rRNA gene primers amplified a major fragment slightly larger than $1.5 \mathrm{~kb}$ from each isolate. Cloning the amplified fragments into pCR2.1 enabled sequencing of the whole amplicons which varied from 1505 to $1507 \mathrm{bp}$. When aligned and compared with 16S rRNA gene sequences available in the GenBank database, the most closely related organisms were different isolates of Steptococcus dysgalactiae $(96.5 \%)$. The first 48 items of the search indicated similarity to different species of streptococci. 
Table 5. Characteristics of Streptococcus didelphis, Streptococcus dysgalactiae and Streptococcus uberis

\begin{tabular}{|c|c|c|c|}
\hline Characteristic* & S. didelphis $\dagger$ & S. dysgalactiae & S. uberist \\
\hline VP & - & 0 & 100 \\
\hline HIP & + & 0 & 99 \\
\hline ESC & - & 0 & 100 \\
\hline PYRA & - & 0 & 16 \\
\hline$\alpha \mathrm{GAL}$ & $\mathrm{v}(8 / 9,-)$ & 0 & 10 \\
\hline$\beta \mathrm{GUR}$ & + & 100 & 92 \\
\hline$\beta \mathrm{GAL}$ & - & 0 & 1 \\
\hline PAL & + & 100 & 30 \\
\hline LAP & + & 100 & 100 \\
\hline $\mathrm{ADH}$ & $\mathrm{v}(7 / 9,+)$ & 100 & 100 \\
\hline RIB & + & 100 & 99 \\
\hline ARA & - & 0 & 0 \\
\hline MAN & - & 0 & 99 \\
\hline SOR & - & 50 & 99 \\
\hline LAC & $\mathrm{v}(8 / 9-)$ & 96 & 100 \\
\hline TRE & + & 100 & 100 \\
\hline INU & - & 0 & 99 \\
\hline RAF & $\mathrm{v}(8 / 9,-)$ & 0 & 7 \\
\hline AMD & $\mathrm{v}(5 / 9,+)$ & 99 & 66 \\
\hline GLYG & - & 30 & 23 \\
\hline$\beta$ HAEM & + & 0 & 0 \\
\hline SAL & - & & \\
\hline OPT & Resistant & Resistant & Resistant \\
\hline
\end{tabular}

*VP, acetoin production; HIP, hippurate hydrolysis; ESC: $\beta$-glucosidase; PYRA, pydrrolidonyl arylamidase; $\alpha \mathrm{GAL}, \alpha$-galactosidase; $\beta \mathrm{GUR}, \beta$-glucuronidase; $\beta \mathrm{GAL}, \beta$-galactosidase; PAL, alkaline phosphatase; LAP, leucine arylamidase; $\mathrm{ADH}$, arginine dihydrolase; RIB, acid from ribose; ARA, acid from L-arabinose; MAN, acid from mannitol; SOR, acid from sorbitol; LAC, acid from lactose; TRE, acid from trehalose; INU, acid from inulin; RAF, acid from raffinose; AMD, acid from starch; GLYG, acid from glycogen; SAL, acid from salicin; $\beta$ HAEM, $\beta$-haemolysis on $5 \%$ sheep-blood agar; OPT, susceptibility to growth inhibition by ethyl hydrocuprein hydrochloride.

$\dagger$ Consistent results are presented as positive $(+)$ or negative $(-)$. Variable results $(v)$ are followed by the number of isolates giving the predominant test result.

$\$$ Percentage positive reactions expected for Streptococcus dysgalactiae and Streptococcus uberis (bioMérieux).

Parsimony and maximum-likelihood inferral methods yielded indistinguishable trees which all indicated the close relationship between the new isolate and Streptococcus dysgalactiae (Fig. 1).

The similarity-matrix-based pairwise comparison of $16 \mathrm{~S}$ rRNA gene sequences of some streptococcal species and the new isolates indicated that the similarity among different strains of Streptococcus dysgalactiae was $>99 \%$, whereas its similarity with other Streptococcus species varied from 94 to $97 \%$. The similarity of $16 \mathrm{~S}$ rRNA gene sequences among the nine new isolates was $>99 \%$, but its similarity with the closest Streptococcus species (Streptococcus dysgalactiae) varied from $94 \cdot 1$ to $96 \cdot 5 \%$.

\section{DISCUSSION}

Catalase-positive streptococci were consistently isolated from lung, kidney, liver, spleen and skin lesions from nine opossums presenting a septicaemic syn- drome. Isolation of this organism in almost pure culture on primary culture from the lungs, spleens, kidneys and livers of the affected animals would imply the involvement of the agent in the disease syndrome.

Bergey's Manual of Systematic Bacteriology describes streptococci as Gram-positive, catalase-negative, facultatively anaerobic bacteria that are spherical or ovoid, $<2 \mu \mathrm{m}$ diameter, occurring in pairs or chains of varying lengths (Hardie, 1986). Morphological characteristics, biochemical tests (Table 5) and cell-wall fatty acid analysis were consistent with identifying the bacteria under study as streptococci, despite the positive catalase reaction.

The catalase activity shown by these isolates is unique among Streptococcus spp. On testing of colonies lifted from the surface of blood-containing agar media, as is frequently performed in diagnostic laboratories, the isolates produce strong positive reactions similar to those of Staphyloccus spp., completely unlike the weak 


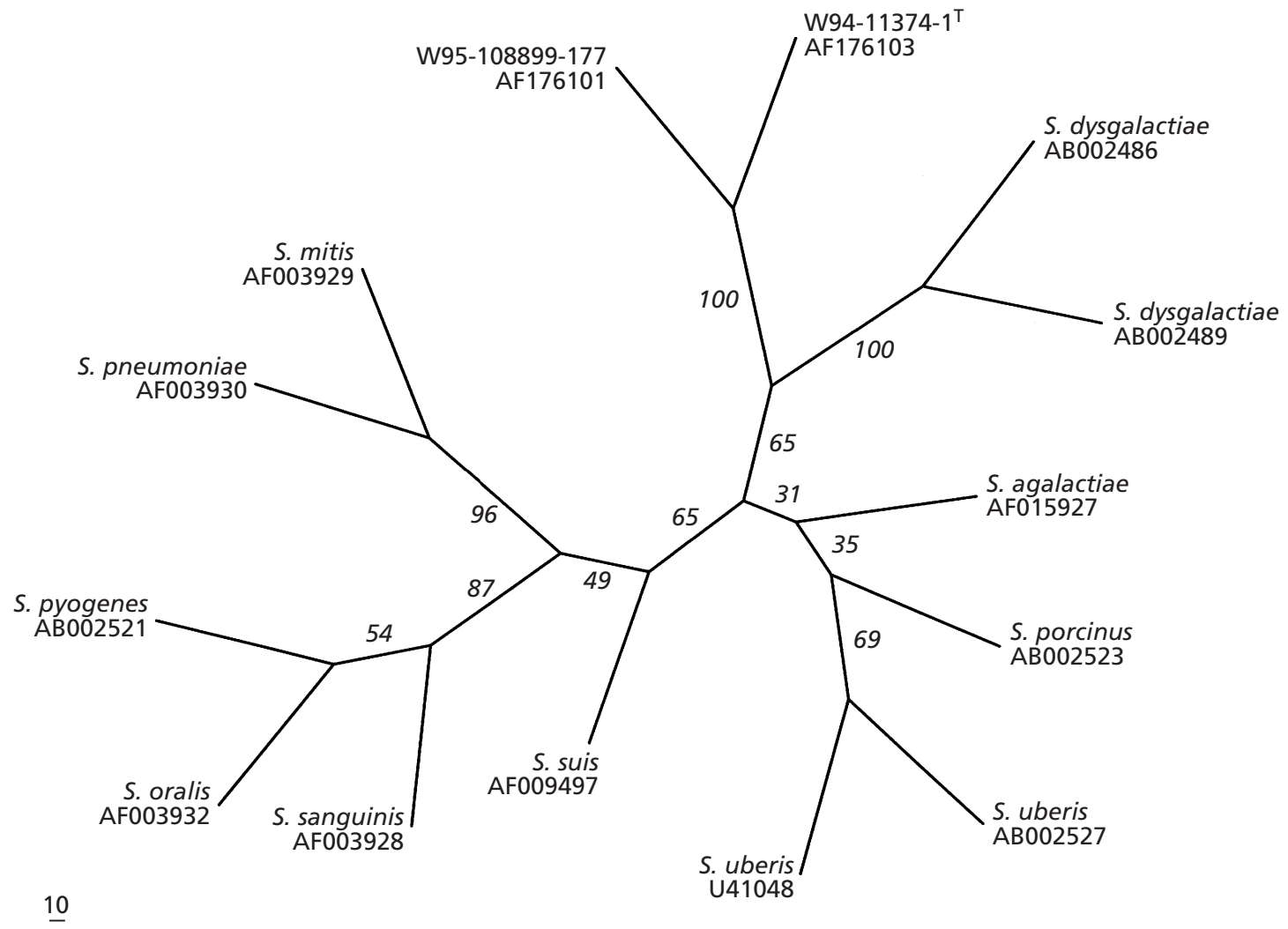

Fig. 1. Phylogenetic unrooted tree showing relationships among various streptococcal species and two of the new streptococcus isolates (W95-108899-177 and W94-11374-1 ${ }^{\top}$ ). The tree was established from an analysis of the sequences (accession numbers after the name) by using DNAPARS and CONSENSE of the PHYLIP package. The value on each branch is the estimated confidence limit (expressed as a percentage) for the position of the branch as determined by bootstrap analysis.

reactions shown by some enterococci and lactobacilli. Furthermore, this strong reaction is maintained on first passage on non-blood containing agar media. Therefore, these isolates will not be satisfactorily identified using routine laboratory protocols that rely on catalase activity testing for identification of Grampositive cocci.

PCR and automated DNA sequencing technologies, together with the availability of large, public-domain molecular sequence databases, have permitted the development of a new approach to the identification of disease-associated micro-organisms, based on analysis of amplified 16S rRNA gene sequences (Hills et al., 1996; Swofford et al., 1996). This approach has been used in the identification of both nonculturable pathogens and less fastidious but unexpected organisms which are not identified or detected by more commonly used methods (La Scola et al., 1997; Relman et al., 1990, 1992; Tee et al., 1996).

Analysis of 16S rRNA gene sequences of the bacterial isolates under study indicated that they belonged to the genus Streptococcus, as revealed by the 48 closest matches from searches of the GenBank database. While consistent with an identification of opossum isolates in the genus Streptococcus, the 16S rRNA was significantly different from those of all named streptococcal species in the database. The closest matches were different strains of Streptococcus dysgalactiae with $96 \cdot 0-96 \cdot 5 \%$ sequence similarity. This relationship was also supported by the generation of identical phylogenetic trees using parsimony and maximumlikelihood methods (Fig. 1), indicating that the organisms under study were most closely related to Streptococcus dysgalactiae. However, alignment of rRNA gene sequences of different strains of Streptococcus dysgalactiae demonstrated sequence similarity of between $99.6 \%$ and $99.9 \%$, indicating that the streptococci under study were not close enough to Streptococcus dysgalactiae to be of the same species. The difference was further demonstrated by the close similarity among the 16S rRNA gene sequences (99.7$100 \%$ ) of the organisms under study as opposed to the similarity to Streptococcus dysgalactiae (96.5\%). This indicated that the organism under study belonged to the genus Streptococcus but did not fit in any of the known species. We therefore propose Streptococcus didelphis sp. nov. as the name of the isolates described in this paper.

The invasive nature of this organism in opossums resembles that described for Streptococcus pyogenes 
group A, usually called Group A Streptococcus (GAS), in humans. GAS invasiveness is attributed mainly to elaboration of streptococcal pyrogenic exotoxin B (SpeB), a conserved cysteine protease expressed by virtually all Streptococcus pyogenes strains (Burns et al., 1998; Lukomski et al., 1997, 1998). It would be interesting to delineate the virulence factors associated with Streptococcus didelphis and the role catalase may play in its virulence.

\section{Description of Streptococcus didelphis sp. nov.}

Streptococcus didelphis (di.del'phis. M.L. Gr.-derived n. Didelphis taxonomic genus name of the American opossum; M.L. gen. n. didelphis of the opossum).

Currently includes isolates from nine opossums, of which WADDL $94-11374-1^{\mathrm{T}}$ is the type strain (= ATCC $700828^{\mathrm{T}}$ ). Isolated from the tissues of opossums with suppurative dermatitis and hepatic fibrosis. Grows on CBA with $\beta$-haemolytic small translucent colonies and does not grow on MacConkey agar. Like other streptococci, the cells are Gram-positive cocci that grow in chains in broth media. Not typeable with Lancifield antisera. The most distinguishing characteristic of S. didelphis compared to other Streptococcus species is the strongly positive catalase reaction on initial passages after growth on blood agar. Additional characteristics are listed in Table 5. For a newly identified strain of Streptococcus to be described as $S$. didelphis, it has to be $\beta$-haemolytic, catalase-positive on initial passage on non-blood-containing media after growth on blood-containing media and a full length of 16S rRNA gene of the new isolate may not differ from S. didelphis $16 \mathrm{~S}$ rRNA gene sequence by $>1.5 \%$.

\section{ACKNOWLEDGEMENTS}

We would like to thank Professor Dr Hans G. Truper for checking the appropriateness of the name. This work was conducted as part of the work of the Washington Animal Diseases Diagnostic Laboratory.

\section{REFERENCES}

Burns, E. H., Jr, Lukomski, S., Rurangirwa, J., Podbielski, A. \& Musser, J. M. (1998). Genetic inactivation of the extracellular cysteine protease enhances in vitro internalization of group A streptococci by human epithelial and endothelial cells. Microb Pathog 24, 333-339.

Carter, G. R., Chengappa, M. M. \& Roberts, A. W. (1995). Streptococcus. In Essentials of Veterinary Microbiology, 5th edn, pp. 109-114. Edited by G. R. Carter, M. M. Chengappa \& A. W. Roberts. Baltimore: Williams \& Wilkins.

Felsenstein, J. (1993). PHYLIP: phylogeny inference package, version 3.5c. Seattle: University of Washington.

Hardie, J. M. (1986). Genus Streptococcus Rosenbach 1884, $22^{\mathrm{AL}}$. In Bergey's Manual of Systematic Bacteriology, vol. 2, pp.
1043-1071. Edited by P. H. A. Sneath, N. S. Mair, M. E. Sharpe \& J. G. Holt. Baltimore: Williams \& Wilkins.

Higgins, D. S. \& Sharp, P. M. (1989). Fast and sensitive multiple sequence alignments on a microcomputer. CABIOS 5, 151-153.

Hills, D. M., Mable, B. K., Larson, A., Davis, S. K. \& Zimmer, E. A. (1996). Nucleic acids IV: sequencing and cloning. In Molecular Systematics, 2nd edn, pp. 321-381. Edited by D. M. Hills, C. Moritz \& B. K. Mable. Sunderland, MA: Sinauer Associates.

La Scola, B., Michel, G. \& Raoult, D. (1997). Use of amplification and sequencing of the $16 \mathrm{~S}$ rRNA gene to diagnose Mycoplasma pneumoniae osteomyelitis in a patient with hypogammaglobulinemia. Clin Infect Dis 24, 1161-1163.

Lukomski, S., Sreevatsan, S., Amberg, C., Reichardt, W., Woischnik, M., Podbielski, A. \& Musser, J. M. (1997). Inactivation of Streptococcus pyogenes extracellular cysteine protease significantly decreases mouse lethality of serotype M3 and M49 strains. J Clin Invest 99, 2574-2580.

Lukomski, S., Burns, E. H., Jr, Wyde, P. R., Podbielski, A., Rurangirwa, J., Moore-Poveda, D. K. \& Musser, J. M. (1998). Genetic inactivation of an extracellular cysteine protease (SpeB) expressed by Streptococcus pyogenes decreases resistance to phagocytosis and dissemination to organs. Infect Immun 66, 771-776.

Master, R. N. (1994). Mycobacteriology. In Clinical Microbiology Procedures Handbook, section 3.1.2. Edited by H. D. Isenberg and others. Washington, DC: American Society for Microbiology.

Pearson, W. R. \& Lipman, D. J. (1988). Improved tools for biological sequence comparison. Proc Natl Acad Sci USA 85, 2444-2448.

Relman, D. A., Loutit, J. S., Schmidt, T. M., Falkow, S. \& Thompkins, L. S. (1990). The agent of bacillary angiomatosis: an approach to the identification of uncultured pathogens. $N$ Engl $J$ Med 323, 1573-1580.

Relman, D. A., Schmidt, T. M., MacDermott, R. P. \& Falkow, S. (1992). Identification of the uncultured bacillus of Whipple's disease. $N$ Engl J Med 337, 293-301.

Ruoff, K. L. (1995). Streptococcus. In Manual of Clinical Microbiology, 6th edn, pp. 299-314. Edited by P. R. Murray and others. Washington, DC: American Society for Microbiology.

Rurangirwa, F. R., Dilbeck, P. M., Crawford, T. B., McGuire, T. C. \& MacElwain, T. F. (1999). Analysis of 16S rRNA gene of the microorganism WSU 86-1044 from an aborted bovine foetus reveals that it is a member of the order Chlamydiales: proposal of Waddliaceae fam. nov., Waddlia chondrophila, gen. nov., sp. nov. Int J Syst Bacteriol 49, 577-581.

Swofford, D. L., Olsen, G. J., Waddell, P. J. \& Hills, D. M. (1996). Phylogenetic inference. In Molecular Systematics, 2nd edn, pp. 407-514. Edited by D. M. Hills, C. Moritz \& B. K. Mable. Sunderland, MA: Sinauer Associates.

Tee, W., Dyall-Smith, M., Woods, W. \& Eisen, D. (1996). Probable new species of Desulfovibrio isolated from a pyogenic liver abscess. J Clin Microbiol 34, 1760-1764.

Wilson, K. H., Blitchington, R. B. \& Greene, R. C. (1990). Amplification of bacterial $16 \mathrm{~S}$ ribosomal DNA with polymerase chain reaction. J Clin Microbiol 28, 1942-1946.

Woese, C. R. (1987). Bacterial evolution. Microbiol Rev 51, 221-271. 